\title{
Ubiquitin Regulation: The Histone Modifying Enzyme's Story
}

\author{
Jianlin Wang ${ }^{1,2}$, Zhaoping Qiu ${ }^{1,2}$ and Yadi $\mathrm{Wu}^{1,2, *}$ \\ 1 Department of Pharmacology \& Nutritional Sciences, University of Kentucky School of Medicine, Lexington, \\ KY 40506, USA; jianlin.wang@uky.edu (J.W.); zhaoping.qiu@uky.edu (Z.Q.) \\ 2 Markey Cancer Center, University of Kentucky School of Medicine, Lexington, KY 40506, USA \\ * Correspondence: yadi.wu@uky.edu; Tel.: +1-859-323-4589; Fax: +1-859-257-6030
}

Received: 26 July 2018; Accepted: 23 August 2018; Published: 27 August 2018

\begin{abstract}
Histone post-translational modifications influence many fundamental cellular events by regulating chromatin structure and gene transcriptional activity. These modifications are highly dynamic and tightly controlled, with many enzymes devoted to the addition and removal of these modifications. Interestingly, these modifying enzymes are themselves fine-tuned and precisely regulated at the level of protein turnover by ubiquitin-proteasomal processing. Here, we focus on recent progress centered on the mechanisms regulating ubiquitination of histone modifying enzymes, including ubiquitin proteasomal degradation and the reverse process of deubiquitination. We will also discuss the potential pathophysiological significance of these processes.
\end{abstract}

Keywords: ubiquitin; epigenetic; histone modifying enzyme; protein degradation

\section{Introduction}

Genomic DNA is tightly packaged in chromatin by both histone and non-histone proteins in the nucleus of eukaryotic cells [1]. The basic chromatin subunits, nucleosomes, are formed by wrapping 146 base pairs of DNA around an octamer core of four histones: H2A, H2B, H3, and $\mathrm{H} 4$ [2,3]. Whereas the nucleosomal core is compact, eight flexible lysine-rich histone tails protrude from the nucleosome, which facilitate internucleosomal contacts and provide binding sites for non-histone proteins [4]. The histones with lysine-rich tails are highly modified by histone post-translational modifications (PTMs) including acetylation, methylation, phosphorylation, ubiquitination, sumoylation, adenosine diphosphate (ADP) ribosylation, proline isomerization, biotinylation, citrullination and their various combinations [5]. These modifications constitute a unique "code" to regulate histone interactions with other proteins and thereby allow for modifications, either overcoming or solidifying, the intrinsic histone barrier to transcription. Histone modifications control dynamic transitions between transcriptionally active or silent chromatin states, and regulate the transcription of genetic information encoded in DNA (the "genetic code") [6]. Accordingly, with these modifications, the various proteins that add, recognize and remove these PTMs, termed writers, readers and erasers, respectively, have been identified and structurally characterized. While "writer" and "eraser" enzymes modify histones by catalyzing the addition and removal of histone PTMs, respectively, "reader" proteins recognize these modified histones and "translate" the PTMs by executing distinct cellular programs. Interestingly, the stability of these "writer", "eraser" and "reader" proteins is dynamically regulated by the ubiquitination proteasome system (UPS). The UPS alters the localization of these proteins and can promote or interfere with protein interactions, providing an additional layer to dynamic transcriptional regulation. The turnover of histone modifying enzymes through the UPS is an intrinsic cellular control mechanism that restricts an association of the enzymes with transcriptional 
factors and rapidly removes the enzymes from chromatin to rigorously regulate chromatin architecture and transcriptional activity.

The 76-residue protein, ubiquitin, is ubiquitously expressed and highly conserved in all eukaryotes. Ubiquitin is covalently attached to an internal lysine residue of its substrates by an enzymatic cascade, that includes an ubiquitin-activating enzyme (E1), a conjugating enzyme (E2) and a ubiquitin ligase (E3) [7]. First, an E1 recruits and activates ubiquitin by formation a thiol-ester bond between a cysteine residue of E1 and the carboxyl terminus of ubiquitin [8]. The activated ubiquitin molecule is subsequently transferred to one of several E2 ubiquitin conjugating enzymes, also through a thiol-ester linkage with ubiquitin. Subsequently, E2 mediates the transfer while the E3 provides specificity by binding to the substrate and recruiting ubiquitin to the conjugation machinery through protein-protein interaction with the E2 enzyme [9]. Most organisms have only one E1, but dozens of different E2s, and more than one thousand E3s, providing effective substrate specificity. Although the E3 ubiquitin ligase is substrate-specific, one E3 ligase may control the degradation of a variety of substrate proteins [10]. In addition, a protein could be ubiquitinated by more than one E3 ubiquitin ligase [11]. Interestingly, many substrates are modified by phosphorylation, acetylation or methylation, which act as molecular recognition signals to recruit ubiquitin E3 ligase complexes [9,12].

Ubiquitination is a reversible process and ubiquitin moieties are removed from polypeptides by deubiquitinases (DUBs), a superfamily of cysteine proteases and metalloproteases that cleave ubiquitin-protein bonds [13]. DUBs may thus counteract specific processes by removing mono-ubiquitin or poly-ubiquitin moieties from various substrates like histones, proteasome substrates and other proteins. The human genome encodes approximately 100 DUBs, which are classified into six families: (1) ubiquitin C-terminal hydrolase (UCH), (2) ubiquitin-specific processing proteases (USP), (3) Jab1/Pad1/MPN domain containing metallo-enzymes (JAMM), (4) OTU domain ubiquitin-aldehyde binding proteins (OTU), (5) Machado-Joseph disease protein domain proteases (MJDs), and (6) the monocyte chemotactic protein-induced protein (MCPIP) family [14]. In addition to deubiquitylation activities, DUBs are involved in processing newly synthesized, inactive ubiquitin precursors. By degrading ubiquitin chains, DUBs generate free ubiquitin, thus, replenishing the ubiquitin pool and maintaining the ubiquitin homeostasis [15]. Therefore, these enzymes add an extra layer in the regulation of cellular functions.

The PTMs regulated by histone modifying enzymes play an important role in gene transcriptional activity. Rapid removal of these histone modifying enzymes from the correct histone is critical to repress or activate any target genes. The UPS controls the availability of histone modifying enzymes and indirectly alters the epigenetic code, which enables transcriptional reprogramming to control the regulation of gene expression in response to different stimuli (Figure 1). Understanding the molecular mechanism for UPS degradation of histone modifying enzymes in different pathophysiological conditions will provide new insights into how histone modifying enzymes respond to different signaling cascades and exert their diverse functions. 


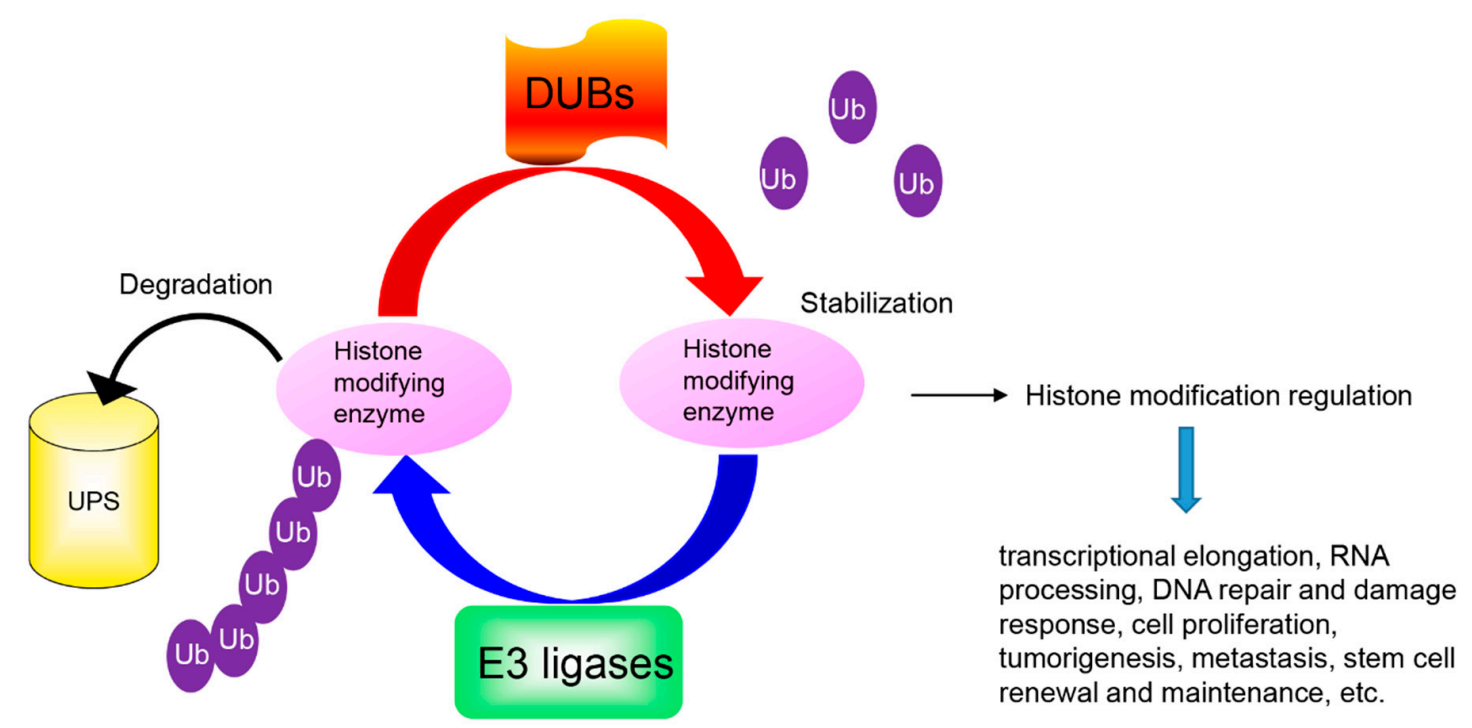

Figure 1. The ubiquitin proteasomal system degrades histone modifying enzymes. Histone modifying enzyme is ubiquitinated and degraded by a ubiquitin ligase (E3) while histone modifying enzyme is stabilized by deubiquitinases (DUBs) through deubiquitination. UPS = ubiquitination proteasome system; $\mathrm{Ub}=$ Ubiquitin.

\section{Ubiquitin Proteasomal Degradation of Histone Acetylation Enzymes}

Histone acetylation is a rapid and reversible process controlled by histone acetyltransferases (HATs) and histone deacetylases (HDACs). The HATs transfer acetyl groups from acetyl-coenzyme A (CoA) to the $\varepsilon$-amino groups of lysine residues of histone tails, which results in gene activation. HATs can be categorized into three major families, GNAT (GCN5 and PCAF), MYST (Tip60 and $\mathrm{MOF}$ ), and p300. The HDACs remove acetyl groups from lysine residues, leading to gene silencing. Genome-wide mapping of HATs and HDACs that bind to the human genome demonstrate that these enzymes regulate the activation and repression of transcription, respectively. A dysfunctional balance between acetylation and deacetylation is clearly associated with human disease and tumorigenesis.

\subsection{Histone Acetyltransferases}

\subsection{1. $\mathrm{p} 300$}

The p300 protein is a histone acetyltransferase and is ubiquitously expressed in the nucleus. P300 catalyzes the acetylation of lysine residues in histone proteins H2AK5, H2B (K5, K12, K15, K20), $\mathrm{H} 3$ (K14, K18, K23), and $\mathrm{H} 4$ (K5, K8, K12) [16]. In addition to histones, other nuclear proteins are also acetylated by p300, such as components of the RNA pol II complex (TFIIE and TFIIF) and a diverse group of transcription factors [17]. P300-mediated histone tail acetylation loosens up the contacts between histones and DNA, which relaxes the chromatin structure to facilitate gene transcription. P300 is essential for cell growth, proliferation, development, differentiation, cell-cycle regulation, DNA damage response, tumorigenesis, and apoptosis in many biologic processes [18,19].

The p300 protein level is tightly and spatially regulated through UPS degradation. P300 is degraded both in the cytoplasm and in the nucleus through distinct mechanisms. P300 turnover by UPS degradation was first identified in human cardiac myocytes [20]. Mdm2 (murine double minute 2), in the presence of active H-Ras or N-Ras, induces p300 degradation in NIH 3T3 cells [21]. Degradation of p300 is also initiated by phosphorylation of p300 at serine 1834, which is catalyzed by the cooperative action of p38 mitogen-activated protein kinases and Akt kinases [22]. The prompt degradation of p300 facilitates the sequential recruitment of downstream repair proteins for successful execution of nucleotide excision repair. Moreover, several additional E3 ligases of p300 have been 
identified in response to distinct upstream signals. For example, Fbx3 ubiquitin ligase promotes the degradation of p300 by the UPS in the nucleus [23]. In contrast, PML protects p300 from Fbx3-induced degradation. In addition, breast cancer metastasis suppresser 1 (BRMS1) acts as bona fide E3 ligase and as such promotes polyubiquitination and proteasome-mediated degradation of p300 [24]. Similar to the bacterial E3 IpaH family of E3 ligase, BRMS1 contains an evolutionarily conserved CXD motif that may be critical for its E3 ligase function. Mutation of this E3 ligase motif abolishes BRMS1-induced p300 polyubiquitination and degradation [24]. In agreement with this finding, inhibitory member of the apoptosis-stimulating protein of p53 (iASPP) stabilizes p300 by interfering with their BRMS1-mediated ubiquitination and enhances apoptosis upon DNA damage [25].

\subsubsection{PCAF (p300/CBP-Associated Factor)}

PCAF interacts with CBP through its amino terminal portion and has sequence similarity with GCN5 in the carboxy-terminal half [26]. PCAF is a transcriptional co-activator with intrinsic HAT activity that acetylates free histone $\mathrm{H} 3$, nucleosomal $\mathrm{H} 3 \mathrm{~K} 14$ and $\mathrm{H} 4 \mathrm{~K} 8$, along with other non-histone proteins including $\mathrm{p} 53$ to regulate transcriptional activity [26,27]. PCAF associates with enhancer sequences to facilitate long-distance transcriptional enhancement. In addition, PCAF interacts with RNA polymerase II to maintain efficient transcriptional elongation. PCAF plays a role in multiple biological and pathogenic process such as proliferation, differentiation, apoptosis, and cell cycle progression. The E3 ubiquitin ligase Mdm2 ubiquitinates and degrades PCAF in the nucleus; devoid of Mdm2's nuclear localization signal sequence, this enzyme is unable to degrade nuclear PCAF [28]. Interestingly, PCAF is not only a HAT, but is also a ubiquitination factor with intrinsic E3 ligase activity. PCAF could function as a ubiquitin E3 ligase for Hdm2, an oncoprotein that promotes p53 degradation, and thus play a role in regulating cellular p53 levels [29]. The potential E3 ligase activity of PCAF is within the so-called PCAF homology domain. In addition, PCAF also acts as a novel E3 ubiquitin ligase of Gli1, the final transcriptional effector of Hedgehog $(\mathrm{Hh})$ signaling. PCAF, but not a mutant with a deletion of its ubiquitination domain, represses Hh signaling in response to DNA damage by promoting Gli1 ubiquitination and subsequent proteasome-dependent degradation [30]. The dual function of PCAF highlights the functional connections between cellular acetylation and ubiquitination machineries.

\subsubsection{HBO1 (Histone Acetyltransferase Binding to Origin Recognition Complex 1)}

HBO1 belongs to the MYST family that modulates cell cycle progression, DNA replication and proliferation [31]. In general, $\mathrm{HBO} 1$ binds upstream of gene transcription start sites and putatively enhances gene expression. HBO1 acetylates H3K14 and histone $\mathrm{H} 4$ to load the origin recognition complex onto chromatin, which initiates DNA replication licensing and triggers DNA replication during the late G1 phase [32]. Ubiquitin-dependent control of the HBO1 protein contributes to cell survival during UV irradiation. HBO1 is degraded after UV-induced DNA damage to suppress cell proliferation; ATM/ATR-dependent phosphorylated HBO1 at Ser50 and Ser53 preferentially interacts with DDB2 and is ubiquitylated by CRL4 (DDB2) [33]. Interestingly, HBO1 is an unstable protein with a half-life around $3 \mathrm{~h}$ [32]. FBXW15 directly interacts with HBO1 to mediate its ubiquitination at K338 in the cytoplasm [32]. Phosphorylation of HBO1 mediated by mitogen-activated protein kinase 1 (Mek1) is required for FBXW15-mediated HBO1 degradation. Silencing FBXW15 blocks the Mek1-mediated HBO1 degradation [32]. Similar to PCAF, HBO1 also has intrinsic ubiquitin E3 ligase activity. $\mathrm{HBO} 1$ promotes destabilization of the estrogen receptor $\alpha(\mathrm{ER} \alpha)$ in breast cancers through lysine 48-linked ubiquitination [34,35]. The acetyltransferase activity of HBO1 is linked to its activity for $\mathrm{ER} \alpha$ ubiquitination.

\subsubsection{Tip60}

Tip60, a member of the MYST family, is expressed ubiquitously and is the acetyltransferase catalytic subunit of the human NuA4 complex [36]. Tip60 specifically targets H2AK5, H4K16 as well 
as other histone proteins. Tip60 plays an important role in many processes, such as cellular signaling, DNA damage repair, transcription and cellular cycling. Aberrant expression of Tip60 promotes or suppresses tumorigenesis in colon, breast and prostate tumors, depending on the tumor type. It is known that Tip60 is turned over in cells by the UPS. UHRF1 (Ubiquitin-like containing PHD and RING domain 1) co-localize with Tip60, and down-regulation of UHRF1 enhances Tip60 expression [37]. By contrast, Tip60 is stabilized in normal cells by UHRF2 ubiquitination and acts downstream of UHRF2 to regulate H3K9ac and H3K14ac expression [38]. Under non-stressed conditions, activating transcription factor-2 (ATF2), in cooperation with the CUL3 ubiquitin ligase promotes degradation of Tip60 [39]. Another important E3 ligase, Mdm2, interacts physically with Tip60 and induces ubiquitination and proteasome-dependent degradation [40]. Recent proteomic analyses further identified EDD1 (E3 identified by differential display), an E3 ligase generally overexpressed in cancers as a novel interacting partner of Tip60 [41]. EDD1 negatively regulates Tip60's stability through the proteasome pathway. Interestingly, $\mathrm{As} 3^{+}$can bind directly to the zinc-finger motif of Tip60 in vitro and exposure to As $3^{+}$results in a dose-dependent decrease in Tip60 protein level via the UPS [42]. However, the mechanism used by $\mathrm{As}^{+}$to regulate Tip60 protein levels remains unknown. Recent studies revealed that ubiquitin-specific protease 7 (USP7) interacts with and deubiquitinates Tip60 both in vitro and in vivo. USP7 deubiquitinase activity is required for the stabilization of Tip60 in order to operate an effective p53-dependent apoptotic pathway in response to genotoxic stress and is central to the development and maintenance of the T regulatory (Treg) cell lineage and adipocyte differentiation [43-46]. The interaction between activating transcription factor 3 (ATF3) and Tip60 increases the Tip60 stability by promoting USP7-mediated deubiquitination of Tip60 [47]. Knockdown of ATF3 expression leads to a decreased Tip60 expression and accumulated DNA lesions and increased cell sensitivity to irradiation.

\subsection{Histone Deacetyltransferases}

\section{HDAC1/HDAC2}

HDAC1, a class I histone deacetyltransferase, is degraded by the UPS. HDAC1 protein levels are degraded robustly between 3 and $4 \mathrm{~h}$ after hormone stimulation as a result of ubiquitination. Destruction of HDAC1 is a common event in transcriptional regulation of nuclear receptors. For example, HDAC1 turnover is increased after glucocorticoids stimulation [48]. In addition, E3 ubiquitin ligase Mdm2 associates with and ubiquitinates HDAC1 at the active promoter in response to androgen [49]. Interestingly, the deacetylase activity of HDAC1 is also required to enhance Mdm2-mediated androgen receptor (AR) ubiquitination. Simultaneous degradation of HDAC 1 and AR by Mdm2 confers protein destabilization and provides an additional mechanism for $\mathrm{AR}$ and $\mathrm{HDAC} 1$ regulation. Mdm2 also induces ubiquitination of $\mathrm{HDAC} 1$ in vascular calcification (VC). Under calcification-inducing conditions, proteasomal degradation of HDAC1 precedes VC and it is mediated by the Mdm2 E3 ubiquitin ligase that initiates HDAC1 K74 ubiquitination [50]. In addition, HDAC1 directly interacts with the carboxyl terminal region of $\mathrm{Chfr}$, an E3 ubiquitin ligase, which contributes to the mitotic checkpoint. Chfr ubiquitinates HDAC1 in vitro and in vivo. Overexpression of Chfr enhances HDAC1 degradation, leading to an upregulation of p21 and the metastasis suppressors KAI1 and E-cadherin [51]. Recently, it was reported that the CUL3-REN E3 ubiquitin ligase complex also triggers HDAC1 recruitment and degradation and, consequently, Gli1 hyperacetylation, which results in inhibition of Gli1's transcriptional activity [52]. Valproic acid (VPA), an inhibitor of Class I and II HDAC enzymes, not only inhibits HDAC catalytic activity but also triggers proteasome-mediated degradation of HDAC2 [53]. The E2 ubiquitin conjugase Ubc8 and the E3 ligase RLIM account for the degradation of HDAC2, which contributes to basal turnover of HDAC2 and is differentially regulated by VPA [53]. Interestingly, both VPA and Trichostatin A (TSA) treatment induce Ubc8 gene expression, whereas only TSA simultaneously reduces RLIM protein levels and therefore fails to induce HDAC2 degradation. Mule (Mcl-1 ubiquitin 
ligase E3), a HECT domain ubiquitin ligase, also specifically targets HDAC2 for ubiquitination and degradation [54]. Accumulation of HDAC2 in Mule-deficient cells leads to compromised p53 acetylation as well as crippled p53 transcriptional activation, accumulation, and apoptotic response upon DNA damage. Interestingly, cigarette smoke extract exposure leads to phosphorylation of HDAC2 by a casein kinase II (CKII)-mediated mechanism, decreased HDAC2 activity, and increased ubiquitin-proteasome-dependent HDAC2 degradation [55]. CKII and proteasome inhibitors stabilize HDAC2 from its degradation. In contrast, ubiquitin-specific peptidase 4 (USP4) interacts directly with and deubiquitinates HDAC2, leading to a stabilization of HDAC2 [56]. Another DUB, USP17, deubiquitinates and stabilizes the protein level of HDAC2. HDAC2 is excessively ubiquitinated and degraded in the proteasome because of low expression of USP17 in cigarette smoke extract-exposed airway epithelial cells and macrophages [57]. Furthermore, over-expression of USP17 attenuates the degradation of HDAC2 induced by cigarette smoke extract.

\section{Ubiquitin Regulation of Histone Methylation Enzymes}

Methylation of lysine residues on histones was first identified in the 1960s. Histone lysines can have four states of methylation and occur at different lysine sites. Histones H2B lysine 5 (H2BK5), H3K4, H3K9, H4K20, H3K27, H3K36, and H3K79 are subject to unmethylated, mono-methylation (me1), di-methylation (me2), or tri-methylation (me3) on the $\varepsilon$-amino groups of lysine residues. These lysine methylations change the chromatin structure to regulate gene transcription. Histone lysine methylation is a reversible modification and is maintained by the balance lysine methyltransferases (KMTs) and lysine demethylases (KDMs). The KMTs recruit S-adenosyl methionine (SAM) as a cofactor and catalyze the addition of methyl groups to lysine residues through the SET domain. The KMTs are grouped into several families: KMT1-3, KMT 5-7, KMT4/DOT1, as well as others. The KDMs include the flavin adenine dinucleotide- (FAD-) dependent monoamine oxidase family (KDM1/LSD (Lysine-Specific Demethylase)), the Jumonji C domain-containing demethylase (JMJD) families (KDM2-6), and others. Methylation of H3K4, H3K36, and H3K79 usually correlate with gene activation, whereas methylation of H3K9, H3K20, H3K27, and H3K56 are associated with transcriptional silencing.

\subsection{Histone Methylation Enzymes}

\subsubsection{SETD2/SETD3 (The SET-Domain Methyltransferase 2/3)}

SETD2 is generally recognized as the only human gene responsible for trimethylation on lysine 36 of Histone $\mathrm{H} 3$ (H3K36), which recruits protein complexes that carry out a variety of processes, including transcriptional elongation, RNA processing, DNA repair and damage response, and polycomb silencing, all of which establish the impact of this histone modification [58,59]. Loss of SETD2 causes regional genomic instability, RNA processing defects, and intragenic transcription initiations. SETD2 functions as a tumor suppressor in cancer progression. In breast cancer, SETD2 expression levels are negatively associated with increasing tumor stage [58]. In gliomas and clear cell renal cell carcinoma, SETD2 is highly mutated [58]. SETD2 has a short half-life [60]. The binding between the WW domain of SETD2 and the C-terminal domain (CTD) of RNA polymerase II (RNAPII) protects SETD2 from degradation. Interestingly, removal of the SETD2-Rpb1 interacting (SRI) domain stabilizes SETD2 in addition to uncoupling SETD2 from the CTD. Thus, the SRI domain contains a degradation signal that becomes exposed when SETD2 is not CTD-bound [60]. A recent study identified SPOP, a key subunit of the CUL3 ligase complex, as a binding partner for SETD2 that mediates its turnover by the proteasome [61]. The SPOP/CUL3 complex is responsible for SETD2 polyubiquitination both in vivo and in vitro. Modulation of SPOP expression confers differential H3K36me3 on SETD2 target genes, and induces H3K36me3-coupled alternative splicing events.

SETD3 is a novel histone H3K4 and H3K36 methyltransferase with transcriptional activation activity. SETD3 levels are increased in human liver cancer cells [62]. Overexpression of SETD3 in liver 
cancer cells promotes cell proliferation and tumorigenesis and SETD3 protein levels correlate with high malignancy and poor prognosis in liver tumors. The SETD3 levels display a dynamic cell cycle profile. SETD3 levels are regulated in a glycogen synthase kinase-3 $\beta$ (GSK-3 $\beta$ )- and F-Box and WD Repeat Domain Containing 7 (FBXW7) $\beta$-dependent manner in the cytoplasm. GSK-3 $\beta$-mediated phosphorylation and FBXW7 $\beta$-mediated ubiquitination of SETD3 are required for its proteolysis [62].

\subsubsection{PR-Set7/Set8 (The SET-Domain Methyltransferase PR-Set7)}

PR-Set7/Set8 (also known as SET8, SETD8 or KMT5A) is a cell-cycle-regulated enzyme that monomethylates the lysine 20 of histone H4 (H4K20) [63]. PR-Set7 plays an essential role in mammalian cell cycle progression, transcriptional regulation, DNA repair, genome stability and tumor metastasis [64]. Set8 and monomethylated H4K20 are virtually undetectable during G1 and S phases of the cell cycle but increase in late $S$ and in $G 2[65,66]$. A timely destruction of this enzyme during $S$ phase is mediated by ubiquitin-mediated proteolysis and requires the interaction of the enzyme with the DNA replication factor proliferating cell nuclear antigen (PCNA) through a conserved PCNA-interacting (PIP) motif located upstream of the catalytic SET domain [67]. PCNA serves as a cofactor to promote PR-Set7 interaction with the CRL4 ${ }^{\text {cdt2 }}$ E3 ubiquitin ligase, which earmarks PR-Set7 for ubiquitylation and degradation during $S$ phase or upon DNA damage [68,69]. PCNA-mediated degradation of mammalian PR-Set7 is essential for proper cell-cycle progression [66,70]. In addition to the CRL4 ${ }^{\text {cdt2 }}$ pathway, the anaphase-promoting complex (APC) $)^{\mathrm{Cdh} 1}$ and the F-box proteins Skp2 and $\beta$-TRCP of SCF ubiquitin E3 ligase complexes are reported to regulate PR-Set7 stability in human cells [67]. Phosphorylation of S28 in PR-Set7 by the cyclin-dependent kinase 1 (CDK1)/cyclinB complex stabilizes PR-Set7 by directly inhibiting its interaction with the APC [70]. In contrast, dephosphorylation of S29 during late mitosis by the Cdc14 phosphatases is required for $\mathrm{APC}^{\mathrm{cdh} 1}$-mediated ubiquitination of PR-Set7 and subsequent proteolysis. Set8 interacts with the $\beta$-TRCP E3 ligase complex including Skp1 and Rbx1 [71,72]. Depletion of either Cullin1, Cullin4 or endogenous $\beta$-TRCP extends the half-life of endogenous Set8 proteins and increases the level of the Set8 protein. CKI (casein kinase I) functions as a key upstream kinase to phosphorylate Set8 at Ser253 and subsequently triggers its destruction by $\beta$-TRCP [71]. Therefore, Set8 is governed by Skp 2 and $\beta$-TRCP in the G1 phase, whereas Set8 destruction is controlled by CRL4 ${ }^{\text {cdt } 2}$ in the $S$ phase. How these ligases fine-tune the timely destruction of Set8 to ensure proper cell cycle progression is unknown.

\subsubsection{EZH2 (Enhancer of Zeste Homolog 2)}

EZH2 is a critical enzymatic subunit of the polycomb repressive complex 2 (PRC2), which silences gene transcription by trimethylating histone $\mathrm{H3}$ (H3K27) to mediate gene repression [73]. Overexpression of EZH2 promotes cell proliferation, tumorigenesis, metastasis, and stem cell renewal and maintenance [74]. EZH2 is mutated or highly expressed in many types of cancer, including lymphoma, melanoma, prostate cancer, and breast cancer [75]. The EZH2 protein is subject to ubiquitin-dependent degradation by several E3 ligases (Figure 2). First, Smurf2 as the E3 ubiquitin ligase is responsible for the polyubiquitination and proteasome-mediated degradation of EZH2, which is required for neuron differentiation [76]. Second, EZH2 is a novel component and substrate of the SCF E3 ubiquitin ligase $\beta$-TRCP (FBXW1) [77]. $\beta$-TRCP ubiquitinates EZH2 while Janus kinases 2 (Jak2)-mediated phosphorylation on Y641 directs the $\beta$-TRCP-mediated EZH2 degradation. Silencing of $\beta$-TRCP or inhibition of Jak2 results in EZH2 stabilization with an attendant increase in H3K27 trimethylation activity. Consistent with this, endogenous EZH2(Y641) mutants exhibit increased EZH2 stability and H3K27me3 hyperactivity in lymphoma cells. Third, EZH2 is a bona fide substrate of FBXW7 in pancreatic cancer cells [78]. EZH2 phosphorylation at Thr 261 by CDK5 kinase is required for FBW7-mediated degradation. FBXW7 suppresses EZH2 activity and inhibits tumor migration and invasion via degradation of EZH2 in pancreatic cancer cells. Fourth, MYOD-induced E3 ubiquitin ligase Praja1 (PJA1) is involved in regulating EZH2 levels upon p38 $\alpha$ activation in differentiating muscle cells [79]. The p38 $\alpha$ kinase promotes EZH2 degradation through phosphorylation of threonine 
372. Premature degradation of EZH2 in proliferating myoblasts is prevented by low levels of PJA1, its cytoplasmic localization and the lower activity with unphosphorylated EZH2. More importantly, FOXP3 accelerates EZH2 protein degradation through the polyubiquitination-proteasome pathway by enhancing the transcription of PJA1 directly [80]. Finally, EZH2 is a substrate at the $\mathrm{COOH}$ terminus of Hsp70-interacting protein (CHIP) [81]. CHIP triggers EZH2 degradation through ubiquitination. Recently, it was reported that the stability of EZH2 was also regulated by long noncoding RNA. Angelman syndrome chromosome region (ANCR) modulates the stability of EZH2, and hence suppresses the invasion and metastasis of breast cancer cells [82]. ANCR potentiates the CDK1-EZH2 interaction, which then increases the extent of phosphorylation at the Thr-345 and Thr- 487 sites of EZH2, facilitating EZH2 ubiquitination and degradation. For the reverse process, EZH2 is stabilized by deubiquitination. Ubiquitin-specific protease (USP21) deubiquitinates EZH2 and stabilizes it. USP21 is upregulated in bladder cancer (BC) and ectopic expression of USP21 is closely associated with tumor size and metastasis [83]. USP21 facilitates cell proliferation, epithelial-mesenchymal transition and metastasis in bladder carcinoma cell lines. ZRANB1, an ovarian tumor protease (OTU) family member, also functions as an EZH2 deubiquitinase [84]. ZRANB1 binds, deubiquitinates, and stabilizes EZH2. Depletion of ZRANB1 in breast cancer cells results in EZH2 destabilization and growth inhibition (Figure 2).

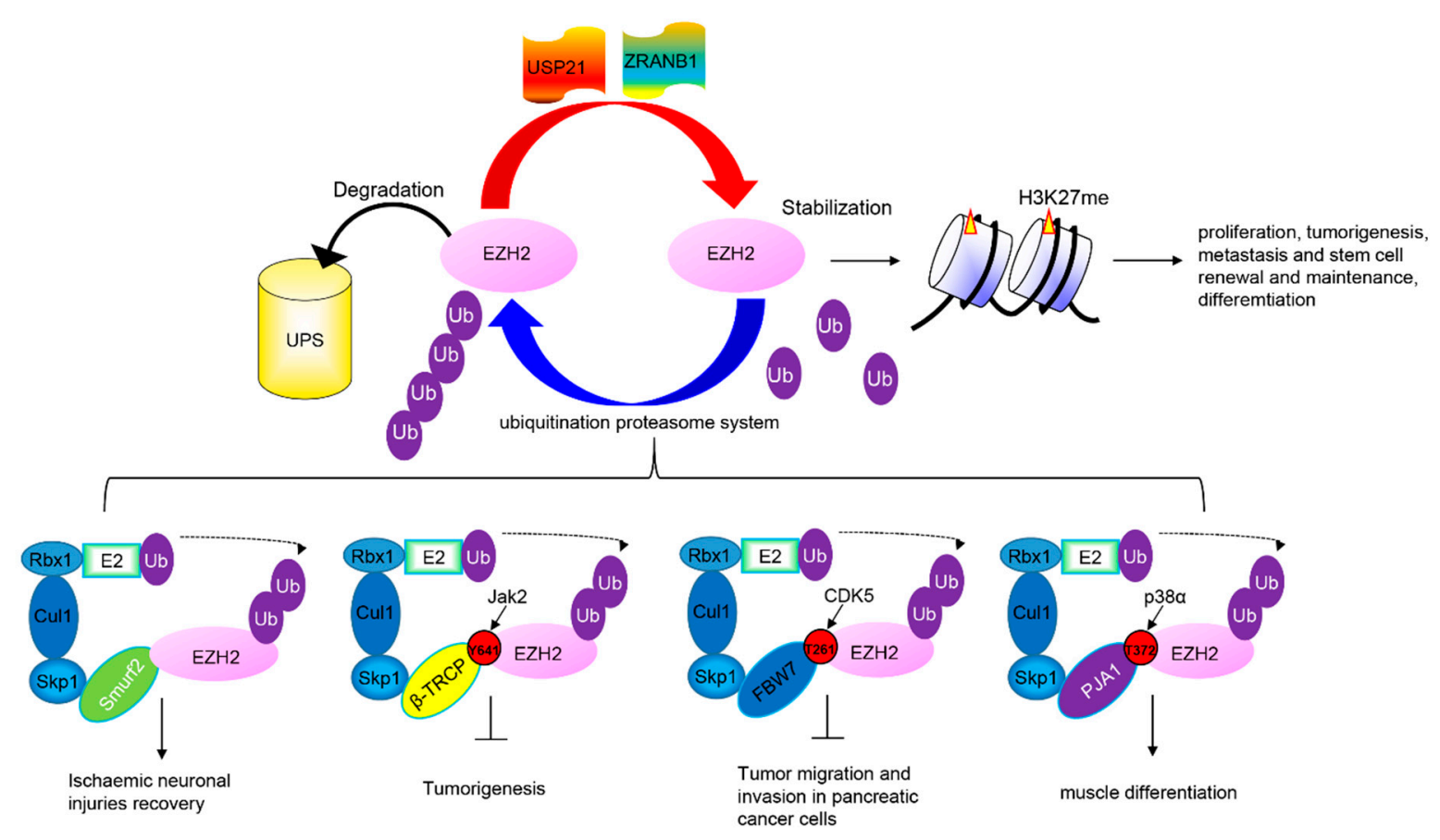

Figure 2. The regulation of EZH2 and related pathologies by the ubiquitin proteasomal system. Composition of the E3 complex and DUB targets EZH2. The Skp-1- Cullin-1-F-Box (SCF) E3s are multimeric E3 ligases that mediates the ubiquitin $(\mathrm{Ub})$ transfers from E2 conjugating enzymes to EZH2.

\subsection{Histone Demethylation Enzymes}

\subsubsection{JMJD2A (Jumonji Domain 2)}

JMJD2A/KDM4A is the first identified histone lysine demethylase that demethylases trimethylated residues and targets H3K9 and H3K36 [85]. The JMJD2 family consists of the three 130-kDa proteins (JMJDA, JMJDB and JMJDC) and JMJD2D/KDM4D, which is half the size and lacks the double PHD and Tudor domains that are epigenome readers and are present in the other KDM4 proteins [86]. JMJD2A is implicated in replication timing and genomic stability, DNA damage response, cellular differentiation, and animal development [85]. Various studies have shown that 
JMJD2A is overexpressed in breast, colorectal, lung, prostate, and other tumors and is required for efficient cancer cell growth [87]. The degradation of JMJD2A is regulated by different F-box-containing SCF ubiquitin ligase complexes. First, JMJD2A turnover is coordinated through the Skp1-Cul1-FBXL4 ubiquitin ligase [88]. The protein degradation of JMJD2A is also regulated by FBXW2 ubiquitin ligase [88]. In addition, FBXO22 ubiquitin ligase complex controls the activity of JMJD2A by targeting it for proteasomal turnover [89]. FBXO22 functions as a receptor for JMJD2A by recognizing its catalytic JmjN/JmjC domains via its intracellular signal transduction (FIST) domain. Modulation of FBXO22 levels by RNA interference or overexpression leads to increased or decreased levels of JMJD2A, respectively. In response to DNA damage, JMJD2A is degraded by the proteasome in an RNF8-dependent manner [90]. RNF8-dependent degradation of JMJD2A regulates DNA repair by controlling the recruitment of 53BP1 at DNA damage sites.

\subsubsection{LSD1 (Lysine-Specific Demethylase 1)}

LSD1, the first identified histone demethylase, functions as an epigenetic regulator through an amine oxidase reaction mainly by removing H3K4 mono-/di-methylation, an activation marker of transcription [91,92]. High levels of the LSD1 have been found in leukemia, non-small cell lung, pancreatic, prostate, and breast cancers [93-96]. Overexpression of LSD1 is associated with tumor aggressiveness, metastasis, recurrence, and drug resistance and is regarded as a biomarker of poor prognosis [97,98]. LSD1 participates in different protein complexes that modulate distinct molecular targets to induce metastasis and cancer stem cells (CSC)s in a variety of cancers [99-103]. For example, we demonstrated that LSD1 interacts with Snail1 and promotes breast cancer metastasis through downregulation of CDH1 [104].

LSD1 is regulated at transcriptional and post-translational levels. We and others showed that LSD1 is under a tight control by the UPS [94,104-106]. We recently found that USP28 is the LSD1 deubiquitinase that stabilizes the LSD1 protein [106]. In addition, USP22 can also stabilize LSD1 through GSK-3 $\beta$-mediated phosphorylation [94]. Furthermore, USP7 inhibits LSD1 ubiquitination and stabilizes LSD1in glioma [107]. USP7-LSD1 affects glioma cell proliferation and invasion. However, the bona fide E3 ligase responsible for LSD1 degradation remains largely unknown. Although Jade2 has been reported to act as an E3 ligase to destabilize LSD1 during neurogenesis [108], this observation is controversial and requires further validation, given that Jade2 is a transcription factor and that Jade2-mediated LSD1 ubiquitination is dependent on the PHD zinc finger of Jade2 rather than a classical ring finger found in almost all E3 ubiquitin ligases [108,109]. Notably, LSD1 harbors canonical (I/L)Q motifs typical for the recognition and ubiquitination by F-box protein [110]. Therefore, it is plausible that the ubiquitination of LSD1 is mediated by an F-box family E3 ligase. Identification of such an E3 ligase and the corresponding mechanism will provide new windows for therapeutic targeting of LSD1.

\section{Ubiquitin of Histone Arginine Methylation Enzymes}

Histone arginine methylation also occurs in many arginine sites: histone H3 arginine 2 (H3R2), H3R8, H3R17, H3R26, and H4R3 undergo monomethylation (me1), symmetrical dimethylation (me2s), or asymmetrical dimethylation (me2a) on the guanidinyl groups of arginine residues. The N-arginine methyltransferases (PRMTs) are a class of enzymes that transfer a methyl group from SAM to the guanidino nitrogen of arginine. PRMTs generate three arginine methylation forms: monomethylarginine (MMA), asymmetric dimethylarginine (aDMA), and symmetric dimethylarginine (sDMA). Human PRMTs are composed of nine members that are categorized into three groups based on the type of arginine methylation reaction each member catalyzes. Type I is comprised of PRMT1, PRMT2, PRMT3, PRMT4/ coactivator-associated arginine methyltransferase 1 (CARM1), PRMT6, and PRMT8; these catalyze both mono-methyl and asymmetric dimethyl arginine reactions. The type II group is made up of two members, PRMT5 and PRMT9, which catalyze both mono-methyl arginine and symmetric dimethyl arginine. Finally, PRMT7 is, at this point, considered the only bona fide 
type III methyltransferase and can generate only mono-methyl arginines. Many studies demonstrated that PRMTs regulate a wide range of genetic programs and cellular processes including cell cycle, RNA splicing and differentiation. Although the consequence of lysine methylation is relatively well studied, the role of PRMT action is poorly understood.

\subsection{PRMT1}

PRMT1 is responsible for a substantial percentage of methylated arginine residues. Specifically, asymmetric dimethylation on H4R3 by PRMT1 is involved in transcriptional activation, thereby driving oncogenic pathways. PRMT1 is an important regulator of cell proliferation, progenitor maintenance, and tumor metastasis. PRMT1 is polyubiquitylated for proteasome degradation with a half-life of approximately $4 \mathrm{~h}$ in lung epithelial cells [111]. FBXL17 mediates PRMT1 polyubiquitination at K117. FBXL17 specifically binds PRMT1 via a unique motif IkxxxIK. The acetylation/deacetylation status of the lysine residues within the motif determines FBXL17 binding thereby triggering PRMT1 protein degradation. The tripartite motif 48 (TRIM48) has a RING-finger motif with E3 ubiquitin ligase activity, and belongs to the TRIM family. TRIM48 promotes K48-linked polyubiquitination and degradation of PRMT1 [112]. Using phage display and the orthogonal UB transfer (OUT) screen, PRMT1 was identified as a potential substrate of the U-box E3 ligase E4B and CHIP [113]. However, the detailed mechanisms of how E4B and CHIP regulate PRMT1 stability need further investigation. Interestingly, PRMT1 regulates E3 ligase activity through arginine methylation. Smurf2 is a substrate of PRMT1 [114] and methylation of Smurf2 by PRMT1 regulates Smurf2 stability and controls TGF- $\beta$ signaling. Another E3 ubiquitin ligase, TNF receptor-associated factor 6 (TRAF6), is also methylated by PRMT1, and this arginine methylation inhibits TRAF6's ubiquitin ligase activity, reducing activation of toll-like receptor signaling [115].

\subsection{PRMT4}

PRMT4, more commonly known as CARM1, is involved in the regulation of a number of cellular processes including transcription, pre-messenger RNA (mRNA) splicing, and cell cycle progression. CARM1 expression is dysregulated in colorectal, prostate and breast cancer. CARM1 methylates the chromatin-remodeling SWI/SNF core subunit, BAF155, in the arginine 1064 residue [116]. This methylation of BAF155 is associated with breast cancer recurrence and metastasis, indicating that CARM1 plays an important role in breast cancer progression through BAF155. Accordingly, CARM1-induced tumorigenic effects and its expression is increased in invasive breast cancer, and correlates with a high tumor grade [117]. Notably, CARM1 stability is regulated by the Skp2-containing SCF (Skp1-cullin1-F-box protein) E3 ubiquitin ligase in the nucleus, but not in the cytoplasm, under nutrient-rich conditions $[118,119]$. With nutrient deprivation, AMP-activated protein kinase (AMPK) induces phosphorylation of FOXO3a in the nucleus, which in turn transcriptionally represses Skp2. Consequently, this repression of Skp2 leads to increased levels of CARM1 protein and a subsequent increase in histone H3 Arg17 dimethylation [119]. Interestingly, high-glucose treatment increases CARM1 ubiquitination [120]. Whether high-glucose treatment increases the Skp2 activity requires further investigation. In addition, peroxide $\left(\mathrm{H}_{2} \mathrm{O}_{2}\right)$ treatment decreases CARM1 protein stability in murine lung epithelial (MLE12) cells, which impedes cell migration through a downregulation of GSK-3 $\beta$. Protein kinase GSK-3 $\beta$ protects CARM1 from ubiquitin proteasomal degradation by catalyzing CARM1 T132 phosphorylation [121].

\section{Ubiquitination of Histone Modification Readers}

\section{BRD4 (Bromodomain Containing 4)}

Histone modifications are recognized by proteins containing distinct recognition domains, which act as "readers" and bind to different histone modifications [122]. For example, the bromodomain acts as a lysine acetylation "reader" of modified histones that mediate signaling transduction changes 
in gene regulatory networks [123]. The bromodomain and the extra-terminal domain (BET) family recognize acetylated lysine residues in histones $\mathrm{H} 3$ and $\mathrm{H} 4$ [124]. BRD4 is a member of the BET family that carries two bromodomains. BRD4 functions as a transcriptional coactivator and plays critical roles in a variety of cellular processes, including the cell cycle, apoptosis, cell proliferation, DNA damage response, autophagy, memory formation and migration and invasion $[125,126]$. BET proteins enhance the oncogenic functions of major cancer drivers by elevating the expression of these drivers, such as c-Myc in multiple myeloma, androgen receptor (AR) and ETS-related gene (ERG) in prostate cancer, and TWIST in breast cancer [127]. BRD4 is frequently overexpressed and clinically associated with a variety of human cancers. BRD4 is also under ubiquitination-mediated degradation. Cullin-3-SPOP earmarks BET proteins, including BRD2, BRD3 and BRD4, for ubiquitination-mediated degradation. SPOP is frequently mutated in primary prostate cancer. Prostate cancer-associated SPOP mutants fail to interact with and promote the degradation of BET proteins, leading to their increased abundance and causing a resistance to BET inhibitors in SPOP-mutant prostate cancer $[125,128,129]$. The E3 ligase substrate receptor cereblon (CRBN) promotes proteosomal destruction by engaging the DDB1-CUL4A-Roc1-RBX1 E3 ubiquitin ligase. Interestingly, dBET1, a chemical compound and targeting ligand, degrades BRD4 by stimulating CRBN's E3 ubiquitin-conjugating function [130]. The degradation of BRD4 can be mitigated by the deubiquitinase DUB3 [131]. DUB3 binds to BRD4 and promotes its deubiquitination and stabilization. DUB3-proficient prostate cancer cells are resistant to the BET inhibitor JQ1 in vitro and in mice.

\section{Conclusions and Perspectives}

Aberrant profiles of histone modifications result in a variety of pathological diseases. The crosstalk between the ubiquitin and histone modifying enzymes and the biochemically reversible nature of histone modifications provides a platform for rapid changes in the activity of downstream targets. The dynamic changes of histone modifying enzymes by UPS form a sophisticated and regulated network to coordinate the plasticity and dynamic change required for cell homeostasis (Table 1).

Because of the rapid progress and appreciation for epigenetics, many factors that regulate the UPS for histone modifying enzymes have been identified. However, more questions have been raised than have been answered. First, what and how do extrinsic cellular signals trigger the degradation of histone modifying enzymes? Second, since most lysine residues function as acceptor sites for ubiquitination, acetylation and methylation, how do these different modifications impact the availability of histone modifying enzymes? Additionally, how do these histone modifying enzymes regulate E3 ligase through different histone modifications? Third, some of the histone modifying enzymes are degraded in the cytoplasm, whereas others are degraded in the nucleus, and the same enzyme can be degraded by different E3 ligases either in the cytoplasm or nucleus. Therefore, how do these E3 ligases cooperate to efficiently control concentrations of these enzymes to meet the requirements for individual cellular homeostasis? Fourth, although specific ubiquitin E3 ligases mediate the ubiquitination of a specific histone modifying enzyme, several histone modifying enzymes share the same E3 ligases. Can these modulators of the UPS be used clinically as therapeutic strategies by altering the abundance of these histone modifying enzymes? Finally, DUBs counteract E3 ligase activity and prevent ubiquitination-mediated degradation. How do these enzymes keep the balance to fine-tune the protein level of histone modifying enzymes?

In all, advances in our understanding of the crosstalk between histone modifying enzymes and the UPS can identify bi-stable switches that allow a dynamic regulation of gene expression states. This understanding will also provide a better sense of the molecular mechanisms associated with histone modification and transcriptional activity, and thus accelerate the development of new therapeutic strategies that target UPS to control PTMs in cellular homeostasis and disease. 
Table 1. The ubiquitin proteasomal regulation of histone modification enzymes.

\begin{tabular}{|c|c|c|c|c|c|c|}
\hline $\begin{array}{c}\text { Class of Histone } \\
\text { Modifying Enzyme }\end{array}$ & $\begin{array}{c}\text { UPS-Regulated } \\
\text { Histone Modifying } \\
\text { Enzyme }\end{array}$ & $\begin{array}{l}\text { Target of the Histone } \\
\text { Modifying Enzyme }\end{array}$ & $\begin{array}{l}\text { Kinases Involved in } \\
\text { UPS-Regulation of } \\
\text { Histone-Modifying Enzyme }\end{array}$ & $\begin{array}{l}\text { E3 ligases } \\
\text { Regulating Histone } \\
\text { Modifying Enzyme }\end{array}$ & $\begin{array}{l}\text { DUBs Regulating } \\
\text { Histone Modifying } \\
\text { Enzyme }\end{array}$ & $\begin{array}{l}\text { Physiological and Pathophysiological Functions of } \\
\text { UPS-Regulation of Histone Modifying Enzyme }\end{array}$ \\
\hline \multirow{4}{*}{ Acetylation Enzyme } & p300 & H2AK5, H2B, H3, H4 & & Mdm2, FBX3, BRMS1 & & $\begin{array}{l}\text { Cell growth, proliferation, development, differentiation, } \\
\text { cell-cycle regulation, DNA damage response, } \\
\text { tumorigenesis and apoptosis }\end{array}$ \\
\hline & PCAF & $\begin{array}{c}\text { Free H3, H3K14, } \\
\text { H4K8 }\end{array}$ & & Mdm2 & & $\begin{array}{l}\text { proliferation, differentiation, apoptosis and } \\
\text { cell-cycle progression }\end{array}$ \\
\hline & $\mathrm{HBO} 1$ & H3K14, H4 & $\begin{array}{l}\text { ATM/ATR } \\
\text { Mek1 }\end{array}$ & $\begin{array}{c}\text { CRL4 } \\
\text { FBXW15 }\end{array}$ & & cell-cycle progression, DNA replication and proliferation \\
\hline & Tip60 & H2AK5, H4K16 & & $\begin{array}{l}\text { UHRF1, EDD1, } \\
\text { Mdm2 }\end{array}$ & USP7 & Cellular signaling, DNA damage repair and transcription \\
\hline \multirow{3}{*}{$\begin{array}{l}\text { Deacetylation } \\
\text { Enzymes }\end{array}$} & HDAC1 & $\mathrm{H} 2 \mathrm{~A}, \mathrm{H} 2 \mathrm{~B}, \mathrm{H} 3, \mathrm{H} 4$ & & Mdm2, Chfr, REN & & Development, gene repression, cell cycle, DNA repair, etc \\
\hline & HDAC2 & $\begin{array}{l}\mathrm{H} 2 \mathrm{~A}, \mathrm{H} 2 \mathrm{~B}, \mathrm{H} 3, \\
\mathrm{H} 4 \mathrm{~K} 16\end{array}$ & & RLIM, Mule & USP4, USP17 & $\begin{array}{l}\text { Differentiation and Development, gene repression, cell } \\
\text { cycle, DNA repair, etc }\end{array}$ \\
\hline & SETD2 & H3К36 & & SPOP & & $\begin{array}{l}\text { Transcription elongation, RNA processing, DNA repair } \\
\text { and damage response, polycomb silencing }\end{array}$ \\
\hline \multirow{3}{*}{$\begin{array}{l}\text { Lysine Methylation } \\
\text { Enzymes }\end{array}$} & SETD3 & H3К36 & GSK3 $\beta$ & FBXW7 $\beta$ & & Cell proliferation and tumorigenesis \\
\hline & Set8 & H3К20 & $\begin{array}{l}\text { CDK1 } \\
\text { CK1 }\end{array}$ & $\begin{array}{c}\text { Cdt2 } \\
\text { Cdh1 } \\
\text { Skp2 } \\
\beta \text {-TRCP }\end{array}$ & & $\begin{array}{l}\text { Cell cycle progression, transcription regulation, DNA } \\
\text { repair, genome stability and tumor metastasis }\end{array}$ \\
\hline & EZH2 & H3К27 & $\begin{array}{l}\text { Jak2 } \\
\text { CDK5 } \\
\text { p38 }\end{array}$ & $\begin{array}{c}\text { Smurf2, CHIP } \\
\beta \text {-TRCP } \\
\text { FBXW7 } \\
\text { Praja1 }\end{array}$ & USP21, ZRANB1 & $\begin{array}{l}\text { Cell proliferation, tumorigenesis, metastasis and stem cell } \\
\text { renewal and maintenance }\end{array}$ \\
\hline \multirow{2}{*}{$\begin{array}{l}\text { Lysine Demethylation } \\
\text { Enzymes }\end{array}$} & JMJD2A & H3K9, H3К36 & & $\begin{array}{l}\text { FBXL4, FBXW2, } \\
\text { FBXO22, RNF8 }\end{array}$ & & $\begin{array}{l}\text { Replication timing and gemomic stability, DNA damage } \\
\text { response, cellular differentiation, and animal development }\end{array}$ \\
\hline & LSD1 & H3K4 & & Jade2 & USP28, USP22, USP7 & Differentiation, self-renewal and tumor metastasis \\
\hline \multirow{2}{*}{$\begin{array}{l}\text { Arginine Methylation } \\
\text { Enzymes }\end{array}$} & PRMT1 & H4R3 & & $\begin{array}{l}\text { FBXL17, TRIM48, } \\
\text { E4B, CHIP }\end{array}$ & & $\begin{array}{l}\text { Cell proliferation, progenitor maintenance and } \\
\text { tumor metastasis }\end{array}$ \\
\hline & PRMT4 & H3R17, H3R26 & & Skp2 & & $\begin{array}{l}\text { Transcription pre- mRNA splicing and cell } \\
\text { cycle progression }\end{array}$ \\
\hline Reader & BRD4 & & & SPOP, CRBN & DUB3 & $\begin{array}{l}\text { Cell-cycle, apoptosis, cell proliferation, DNA damage } \\
\text { response, autophagy, memory formation and migration } \\
\text { and invision }\end{array}$ \\
\hline
\end{tabular}


Author Contributions: All authors contributed to the manuscript content and editing for this review. Y.W. provided supervision and financial support.

Funding: Our research was supported by the Shared Resources of the University of Kentucky Markey Cancer Center (P30CA177558). Our research was also supported by grants from American Cancer Society Research Scholar Award (RSG13187) and NIH (P20GM121327 and CA230758) to Yadi Wu.

Acknowledgments: We thank Cathy Anthony for the critical editing of this manuscript.

Conflicts of Interest: The authors have declared that no conflicts of interest exist.

\section{References}

1. Bernstein, B.E.; Meissner, A.; Lander, E.S. The mammalian epigenome. Cell 2007, 128, 669-681. [CrossRef] [PubMed]

2. Kornberg, R.D.; Lorch, Y. Twenty-five years of the nucleosome, fundamental particle of the eukaryote chromosome. Cell 1999, 98, 285-294. [CrossRef]

3. Richmond, T.J.; Davey, C.A. The structure of DNA in the nucleosome core. Nature 2003, 423, 145-150. [CrossRef] [PubMed]

4. Luger, K.; Richmond, T.J. The histone tails of the nucleosome. Curr. Opin. Genet. Dev. 1998, 8, 140-146. [CrossRef]

5. Tessarz, P.; Kouzarides, T. Histone core modifications regulating nucleosome structure and dynamics. Nat. Rev. Mol. Cell Biol. 2014, 15, 703-708. [CrossRef] [PubMed]

6. Jenuwein, T.; Allis, C.D. Translating the histone code. Science 2001, 293, 1074-1080. [CrossRef] [PubMed]

7. Pickart, C.M. Mechanisms underlying ubiquitination. Annu. Rev. Biochem. 2001, 70, 503-533. [CrossRef] [PubMed]

8. Haas, A.L.; Rose, I.A. The mechanism of ubiquitin activating enzyme. A kinetic and equilibrium analysis. J. Biol. Chem. 1982, 257, 10329-10337. [PubMed]

9. Scheffner, M.; Nuber, U.; Huibregtse, J.M. Protein ubiquitination involving an E1-E2-E3 enzyme ubiquitin thioester cascade. Nature 1995, 373, 81-83. [CrossRef] [PubMed]

10. Xu, C.; Kim, N.G.; Gumbiner, B.M. Regulation of protein stability by GSK3 mediated phosphorylation. Cell Cycle 2009, 8, 4032-4039. [CrossRef] [PubMed]

11. Yoo, S.H.; Mohawk, J.A.; Siepka, S.M.; Shan, Y.; Huh, S.K.; Hong, H.K.; Kornblum, I.; Kumar, V.; Koike, N.; $\mathrm{Xu}, \mathrm{M}$; ; et al. Competing E3 ubiquitin ligases govern circadian periodicity by degradation of CRY in nucleus and cytoplasm. Cell 2013, 152, 1091-1105. [CrossRef] [PubMed]

12. Ravid, T.; Hochstrasser, M. Diversity of degradation signals in the ubiquitin-proteasome system. Nat. Rev. Mol. Cell Biol. 2008, 9, 679-690. [CrossRef] [PubMed]

13. Wilkinson, K.D. Regulation of ubiquitin-dependent processes by deubiquitinating enzymes. FASEB J. 1997, 11, 1245-1256. [CrossRef] [PubMed]

14. Fraile, J.M.; Quesada, V.; Rodriguez, D.; Freije, J.M.; Lopez-Otin, C. Deubiquitinases in cancer: New functions and therapeutic options. Oncogene 2012, 31, 2373-2388. [CrossRef] [PubMed]

15. Hanpude, P.; Bhattacharya, S.; Dey, A.K.; Maiti, T.K. Deubiquitinating enzymes in cellular signaling and disease regulation. IUBMB Life 2015, 67, 544-555. [CrossRef] [PubMed]

16. Valor, L.M.; Viosca, J.; Lopez-Atalaya, J.P.; Barco, A. Lysine acetyltransferases CBP and p300 as therapeutic targets in cognitive and neurodegenerative disorders. Curr. Pharm. Des. 2013, 19, 5051-5064. [CrossRef] [PubMed]

17. Ogryzko, V.V.; Schiltz, R.L.; Russanova, V.; Howard, B.H.; Nakatani, Y. The transcriptional coactivators p300 and CBP are histone acetyltransferases. Cell 1996, 87, 953-959. [CrossRef]

18. Goodman, R.H.; Smolik, S. CBP/p300 in cell growth, transformation, and development. Genes Dev. 2000, 14, 1553-1577. [PubMed]

19. Iyer, N.G.; Ozdag, H.; Caldas, C. P300/CBP and cancer. Oncogene 2004, 23, 4225-4231. [CrossRef] [PubMed]

20. Poizat, C.; Sartorelli, V.; Chung, G.; Kloner, R.A.; Kedes, L. Proteasome-mediated degradation of the coactivator p300 impairs cardiac transcription. Mol. Cell Biol. 2000, 20, 8643-8654. [CrossRef] [PubMed]

21. Sanchez-Molina, S.; Oliva, J.L.; Garcia-Vargas, S.; Valls, E.; Rojas, J.M.; Martinez-Balbas, M.A. The histone acetyltransferases CBP/p300 are degraded in NIH 3T3 cells by activation of Ras signalling pathway. Biochem. J. 2006, 398, 215-224. [CrossRef] [PubMed] 
22. Wang, Q.E.; Han, C.; Zhao, R.; Wani, G.; Zhu, Q.; Gong, L.; Battu, A.; Racoma, I.; Sharma, N.; Wani, A.A. P38 MAPK- and Akt-mediated p300 phosphorylation regulates its degradation to facilitate nucleotide excision repair. Nucleic Acids Res. 2013, 41, 1722-1733. [CrossRef] [PubMed]

23. Shima, Y.; Shima, T.; Chiba, T.; Irimura, T.; Pandolfi, P.P.; Kitabayashi, I. PML activates transcription by protecting HIPK2 and p300 from SCFFbx3-mediated degradation. Mol. Cell Biol. 2008, 28, 7126-7138. [CrossRef] [PubMed]

24. Liu, Y.; Mayo, M.W.; Nagji, A.S.; Hall, E.H.; Shock, L.S.; Xiao, A.; Stelow, E.B.; Jones, D.R. BRMS1 suppresses lung cancer metastases through an E3 ligase function on histone acetyltransferase p300. Cancer Res. 2013, 73, 1308-1317. [CrossRef] [PubMed]

25. Kramer, D.; Schon, M.; Bayerlova, M.; Bleckmann, A.; Schon, M.P.; Zornig, M.; Dobbelstein, M. A pro-apoptotic function of iASPP by stabilizing p300 and CBP through inhibition of BRMS1 E3 ubiquitin ligase activity. Cell Death Dis. 2015, 6, e1634. [CrossRef] [PubMed]

26. Schiltz, R.L.; Nakatani, Y. The PCAF acetylase complex as a potential tumor suppressor. Biochim. Biophys. Acta 2000, 1470, M37-M53. [CrossRef]

27. Blanco, J.C.; Minucci, S.; Lu, J.; Yang, X.J.; Walker, K.K.; Chen, H.; Evans, R.M.; Nakatani, Y.; Ozato, K. The histone acetylase PCAF is a nuclear receptor coactivator. Genes Dev. 1998, 12, 1638-1651. [CrossRef] [PubMed]

28. Jin, Y.; Zeng, S.X.; Lee, H.; Lu, H. MDM2 mediates p300/CREB-binding protein-associated factor ubiquitination and degradation. J. Biol. Chem. 2004, 279, 20035-20043. [CrossRef] [PubMed]

29. Linares, L.K.; Kiernan, R.; Triboulet, R.; Chable-Bessia, C.; Latreille, D.; Cuvier, O.; Lacroix, M.; Le Cam, L.; Coux, O.; Benkirane, M. Intrinsic ubiquitination activity of PCAF controls the stability of the oncoprotein Hdm2. Nat. Cell Biol. 2007, 9, 331-338. [CrossRef] [PubMed]

30. Mazza, D.; Infante, P.; Colicchia, V.; Greco, A.; Alfonsi, R.; Siler, M.; Antonucci, L.; Po, A.; De Smaele, E.; Ferretti, E.; et al. PCAF ubiquitin ligase activity inhibits Hedgehog/Gli1 signaling in p53-dependent response to genotoxic stress. Cell Death Differ. 2013, 20, 1688-1697. [CrossRef] [PubMed]

31. Guo, L.L.; Yu, S.Y.; Li, M. Functional analysis of HBO1 in tumor development and inhibitor screening. Int. J. Mol. Med. 2016, 38, 300-304. [CrossRef] [PubMed]

32. Zou, C.; Chen, Y.; Smith, R.M.; Snavely, C.; Li, J.; Coon, T.A.; Chen, B.B.; Zhao, Y.; Mallampalli, R.K. SCFFfbxw15 mediates histone acetyltransferase binding to origin recognition complex (HBO1) ubiquitin-proteasomal degradation to regulate cell proliferation. J. Biol. Chem. 2013, 288, 6306-6316. [CrossRef] [PubMed]

33. Matsunuma, R.; Niida, H.; Ohhata, T.; Kitagawa, K.; Sakai, S.; Uchida, C.; Shiotani, B.; Matsumoto, M.; Nakayama, K.I.; Ogura, H.; et al. UV damage-induced phosphorylation of HBO1 triggers CRL4DDB2-mediated degradation to regulate cell proliferation. Mol. Cell Biol. 2016, 36, 394-406. [CrossRef] [PubMed]

34. Iizuka, M.; Susa, T.; Takahashi, Y.; Tamamori-Adachi, M.; Kajitani, T.; Okinaga, H.; Fukusato, T.; Okazaki, T. Histone acetyltransferase $\mathrm{HBO} 1$ destabilizes estrogen receptor alpha by ubiquitination and modulates proliferation of breast cancers. Cancer Sci. 2013, 104, 1647-1655. [CrossRef] [PubMed]

35. Iizuka, M.; Susa, T.; Tamamori-Adachi, M.; Okinaga, H.; Okazaki, T. Intrinsic ubiquitin E3 ligase activity of histone acetyltransferase Hbo1 for estrogen receptor $\alpha$. Proc. Jpn. Acad. Ser. B Phys. Biol. Sci. 2017, 93, 498-510. [CrossRef] [PubMed]

36. Judes, G.; Rifai, K.; Ngollo, M.; Daures, M.; Bignon, Y.J.; Penault-Llorca, F.; Bernard-Gallon, D. A bivalent role of TIP60 histone acetyl transferase in human cancer. Epigenomics 2015, 7, 1351-1363. [CrossRef] [PubMed]

37. Achour, M.; Fuhrmann, G.; Alhosin, M.; Ronde, P.; Chataigneau, T.; Mousli, M.; Schini-Kerth, V.B.; Bronner, C. UHRF1 recruits the histone acetyltransferase Tip60 and controls its expression and activity. Biochem. Biophys. Res. Commun. 2009, 390, 523-528. [CrossRef] [PubMed]

38. Zeng, S.; Wang, Y.; Zhang, T.; Bai, L.; Wang, Y.; Duan, C. E3 ligase UHRF2 stabilizes the acetyltransferase TIP60 and regulates H3K9ac and H3K14ac via RING finger domain. Protein Cell 2017, 8, 202-218. [CrossRef] [PubMed]

39. Bhoumik, A.; Singha, N.; O'Connell, M.J.; Ronai, Z.A. Regulation of TIP60 by ATF2 modulates ATM activation. J. Biol. Chem. 2008, 283, 17605-17614. [CrossRef] [PubMed] 
40. Legube, G.; Linares, L.K.; Lemercier, C.; Scheffner, M.; Khochbin, S.; Trouche, D. Tip60 is targeted to proteasome-mediated degradation by Mdm2 and accumulates after UV irradiation. EMBO J. 2002, 21, 1704-1712. [CrossRef] [PubMed]

41. Subbaiah, V.K.; Zhang, Y.; Rajagopalan, D.; Abdullah, L.N.; Yeo-Teh, N.S.; Tomaic, V.; Banks, L.; Myers, M.P.; Chow, E.K.; Jha, S. E3 ligase EDD1/UBR5 is utilized by the HPV E6 oncogene to destabilize tumor suppressor tip60. Oncogene 2016, 35, 2062-2074. [CrossRef] [PubMed]

42. Tam, L.M.; Jiang, J.; Wang, P.; Li, L.; Miao, W.; Dong, X.; Wang, Y. Arsenite binds to the zinc finger motif of TIP60 histone acetyltransferase and induces its degradation via the 26 s proteasome. Chem. Res. Toxicol. 2017, 30, 1685-1693. [CrossRef] [PubMed]

43. Wang, F.; Wang, L.; Wu, J.; Sokirniy, I.; Nguyen, P.; Bregnard, T.; Weinstock, J.; Mattern, M.; Bezsonova, I.; Hancock, W.W.; et al. Active site-targeted covalent irreversible inhibitors of USP7 impair the functions of Foxp3+ T-regulatory cells by promoting ubiquitination of Tip60. PLoS ONE 2017, 12, e0189744. [CrossRef] [PubMed]

44. Wang, L.; Kumar, S.; Dahiya, S.; Wang, F.; Wu, J.; Newick, K.; Han, R.; Samanta, A.; Beier, U.H.; Akimova, T.; et al. Ubiquitin-specific protease-7 inhibition impairs Tip60-dependent Foxp3+ T-regulatory cell function and promotes antitumor immunity. EBioMedicine 2016, 13, 99-112. [CrossRef] [PubMed]

45. Dar, A.; Shibata, E.; Dutta, A. Deubiquitination of Tip60 by USP7 determines the activity of the p53-dependent apoptotic pathway. Mol. Cell Biol. 2013, 33, 3309-3320. [CrossRef] [PubMed]

46. Gao, Y.; Koppen, A.; Rakhshandehroo, M.; Tasdelen, I.; van de Graaf, S.F.; van Loosdregt, J.; van Beekum, O.; Hamers, N.; van Leenen, D.; Berkers, C.R.; et al. Early adipogenesis is regulated through USP7-mediated deubiquitination of the histone acetyltransferase Tip60. Nat. Commun. 2013, 4, 2656. [CrossRef] [PubMed]

47. Cui, H.; Guo, M.; Xu, D.; Ding, Z.C.; Zhou, G.; Ding, H.F.; Zhang, J.; Tang, Y.; Yan, C. The stress-responsive gene ATF3 regulates the histone acetyltransferase Tip60. Nat. Commun. 2015, 6, 6752. [CrossRef] [PubMed]

48. Wiper-Bergeron, N.; Wu, D.; Pope, L.; Schild-Poulter, C.; Hache, R.J. Stimulation of preadipocyte differentiation by steroid through targeting of an HDAC1 complex. EMBO J. 2003, 22, 2135-2145. [CrossRef] [PubMed]

49. Gaughan, L.; Logan, I.R.; Neal, D.E.; Robson, C.N. Regulation of androgen receptor and histone deacetylase 1 by Mdm2-mediated ubiquitylation. Nucleic Acids Res. 2005, 33, 13-26. [CrossRef] [PubMed]

50. Kwon, D.H.; Eom, G.H.; Ko, J.H.; Shin, S.; Joung, H.; Choe, N.; Nam, Y.S.; Min, H.K.; Kook, T.; Yoon, S.; et al. Mdm2 E3 ligase-mediated ubiquitination and degradation of HDAC1 in vascular calcification. Nat. Commun. 2016, 7, 10492. [CrossRef] [PubMed]

51. Oh, Y.M.; Kwon, Y.E.; Kim, J.M.; Bae, S.J.; Lee, B.K.; Yoo, S.J.; Chung, C.H.; Deshaies, R.J.; Seol, J.H. Chfr is linked to tumour metastasis through the downregulation of HDAC1. Nat. Cell Biol. 2009, 11, $295-302$. [CrossRef] [PubMed]

52. Canettieri, G.; Di Marcotullio, L.; Greco, A.; Coni, S.; Antonucci, L.; Infante, P.; Pietrosanti, L.; De Smaele, E.; Ferretti, E.; Miele, E.; et al. Histone deacetylase and Cullin3-REN ${ }^{\mathrm{KCTD} 11}$ ubiquitin ligase interplay regulates hedgehog signalling through Gli acetylation. Nat. Cell Biol. 2010, 12, 132-142. [CrossRef] [PubMed]

53. Kramer, O.H.; Zhu, P.; Ostendorff, H.P.; Golebiewski, M.; Tiefenbach, J.; Peters, M.A.; Brill, B.; Groner, B.; Bach, I.; Heinzel, T.; et al. The histone deacetylase inhibitor valproic acid selectively induces proteasomal degradation of HDAC2. EMBO J. 2003, 22, 3411-3420. [CrossRef] [PubMed]

54. Zhang, J.; Kan, S.; Huang, B.; Hao, Z.; Mak, T.W.; Zhong, Q. Mule determines the apoptotic response to HDAC inhibitors by targeted ubiquitination and destruction of HDAC2. Genes Dev. 2011, 25, 2610-2618. [CrossRef] [PubMed]

55. Adenuga, D.; Yao, H.; March, T.H.; Seagrave, J.; Rahman, I. Histone deacetylase 2 is phosphorylated, ubiquitinated, and degraded by cigarette smoke. Am. J. Respir. Cell Mol. Biol. 2009, 40, 464-473. [CrossRef] [PubMed]

56. Li, Z.; Hao, Q.; Luo, J.; Xiong, J.; Zhang, S.; Wang, T.; Bai, L.; Wang, W.; Chen, M.; Wang, W.; et al. USP4 inhibits p53 and NF-kB through deubiquitinating and stabilizing HDAC2. Oncogene 2016, 35, $2902-2912$. [CrossRef] [PubMed]

57. Song, H.; Tao, L.; Chen, C.; Pan, L.; Hao, J.; Ni, Y.; Li, D.; Li, B.; Shi, G. USP17-mediated deubiquitination and stabilization of HDAC2 in cigarette smoke extract-induced inflammation. Int. J. Clin. Exp. Pathol. 2015, 8, 10707-10715. [PubMed] 
58. Li, J.; Duns, G.; Westers, H.; Sijmons, R.; van den Berg, A.; Kok, K. SETD2: An epigenetic modifier with tumor suppressor functionality. Oncotarget 2016, 7, 50719-50734. [CrossRef] [PubMed]

59. McDaniel, S.L.; Strahl, B.D. Shaping the cellular landscape with Set2/SETD2 methylation. Cell. Mol. Life Sci. CMLS 2017, 74, 3317-3334. [CrossRef] [PubMed]

60. Fuchs, S.M.; Kizer, K.O.; Braberg, H.; Krogan, N.J.; Strahl, B.D. RNA polymerase ii carboxyl-terminal domain phosphorylation regulates protein stability of the Set2 methyltransferase and histone $\mathrm{H} 3$ di- and trimethylation at lysine 36. J. Biol. Chem. 2012, 287, 3249-3256. [CrossRef] [PubMed]

61. Zhu, K.; Lei, P.J.; Ju, L.G.; Wang, X.; Huang, K.; Yang, B.; Shao, C.; Zhu, Y.; Wei, G.; Fu, X.D.; et al. SPOP-containing complex regulates SETD2 stability and H3K36me3-coupled alternative splicing. Nucleic Acids Res. 2017, 45, 92-105. [CrossRef] [PubMed]

62. Cheng, X.; Hao, Y.; Shu, W.; Zhao, M.; Zhao, C.; Wu, Y.; Peng, X.; Yao, P.; Xiao, D.; Qing, G.; et al. Cell cycle-dependent degradation of the methyltransferase SETD3 attenuates cell proliferation and liver tumorigenesis. J. Biol. Chem. 2017, 292, 9022-9033. [CrossRef] [PubMed]

63. Beck, D.B.; Oda, H.; Shen, S.S.; Reinberg, D. PR-Set7 and H4K20me1: At the crossroads of genome integrity, cell cycle, chromosome condensation, and transcription. Genes Dev. 2012, 26, 325-337. [CrossRef] [PubMed]

64. Yin, Y.; Yu, V.C.; Zhu, G.; Chang, D.C. SET8 plays a role in controlling $\mathrm{G}_{1} / \mathrm{S}$ transition by blocking lysine acetylation in histone through binding to $\mathrm{H} 4 \mathrm{~N}$-terminal tail. Cell Cycle 2008, 7, 1423-1432. [CrossRef] [PubMed]

65. Tardat, M.; Brustel, J.; Kirsh, O.; Lefevbre, C.; Callanan, M.; Sardet, C.; Julien, E. The histone H4 Lys 20 methyltransferase PR-Set7 regulates replication origins in mammalian cells. Nat. Cell Biol. 2010, 12, 1086-1093. [CrossRef] [PubMed]

66. Centore, R.C.; Havens, C.G.; Manning, A.L.; Li, J.M.; Flynn, R.L.; Tse, A.; Jin, J.; Dyson, N.J.; Walter, J.C.; Zou, L. CRL4Cdt2-mediated destruction of the histone methyltransferase Set8 prevents premature chromatin compaction in S phase. Mol. Cell 2010, 40, 22-33. [CrossRef] [PubMed]

67. Oda, H.; Hubner, M.R.; Beck, D.B.; Vermeulen, M.; Hurwitz, J.; Spector, D.L.; Reinberg, D. Regulation of the histone $\mathrm{H} 4$ monomethylase PR-Set7 by CRL4Cdt2-mediated PCNA-dependent degradation during DNA damage. Mol. Cell 2010, 40, 364-376. [CrossRef] [PubMed]

68. Abbas, T.; Shibata, E.; Park, J.; Jha, S.; Karnani, N.; Dutta, A. CRL4Cdt2 regulates cell proliferation and histone gene expression by targeting PR-Set7/Set8 for degradation. Mol. Cell 2010, 40, 9-21. [CrossRef] [PubMed]

69. Jorgensen, S.; Eskildsen, M.; Fugger, K.; Hansen, L.; Larsen, M.S.; Kousholt, A.N.; Syljuasen, R.G.; Trelle, M.B.; Jensen, O.N.; Helin, K.; et al. SET8 is degraded via PCNA-coupled CRL4(CDT2) ubiquitylation in S phase and after UV irradiation. J. Cell Biol. 2011, 192, 43-54. [CrossRef] [PubMed]

70. Wu, S.; Wang, W.; Kong, X.; Congdon, L.M.; Yokomori, K.; Kirschner, M.W.; Rice, J.C. Dynamic regulation of the PR-Set7 histone methyltransferase is required for normal cell cycle progression. Genes Dev. 2010, 24, 2531-2542. [CrossRef] [PubMed]

71. Wang, Z.; Dai, X.; Zhong, J.; Inuzuka, H.; Wan, L.; Li, X.; Wang, L.; Ye, X.; Sun, L.; Gao, D.; et al. SCF ${ }^{\beta-T R C P}$ promotes cell growth by targeting PR-Set7/Set8 for degradation. Nat. Commun. 2015, 6, 10185. [CrossRef] [PubMed]

72. Zheng, N.; Dai, X.; Wang, Z.; Wei, W. A new layer of degradation mechanism forPR-Set7/Set8 during cell cycle. Cell Cycle 2016, 15, 3042-3047. [CrossRef] [PubMed]

73. Muller, J.; Hart, C.M.; Francis, N.J.; Vargas, M.L.; Sengupta, A.; Wild, B.; Miller, E.L.; O'Connor, M.B.; Kingston, R.E.; Simon, J.A. Histone methyltransferase activity of a drosophila polycomb group repressor complex. Cell 2002, 111, 197-208. [CrossRef]

74. Yan, K.S.; Lin, C.Y.; Liao, T.W.; Peng, C.M.; Lee, S.C.; Liu, Y.J.; Chan, W.P.; Chou, R.H. EZH2 in cancer progression and potential application in cancer therapy: A friend or foe? Int. J. Mol. Sci. 2017, 18, 1172. [CrossRef] [PubMed]

75. Jones, B.A.; Varambally, S.; Arend, R.C. Histone methyltransferase EZH2: A therapeutic target for ovarian cancer. Mol. Cancer Ther. 2018, 17, 591-602. [CrossRef] [PubMed]

76. Yu, Y.L.; Chou, R.H.; Shyu, W.C.; Hsieh, S.C.; Wu, C.S.; Chiang, S.Y.; Chang, W.J.; Chen, J.N.; Tseng, Y.J.; Lin, Y.H.; et al. Smurf2-mediated degradation of EZH2 enhances neuron differentiation and improves functional recovery after ischaemic stroke. EMBO Mol. Med. 2013, 5, 531-547. [CrossRef] [PubMed] 
77. Sahasrabuddhe, A.A.; Chen, X.; Chung, F.; Velusamy, T.; Lim, M.S.; Elenitoba-Johnson, K.S. Oncogenic Y641 mutations in EZH2 prevent Jak2/ $\beta$-TrCp-mediated degradation. Oncogene 2015, 34, 445-454. [CrossRef] [PubMed]

78. Jin, X.; Yang, C.; Fan, P.; Xiao, J.; Zhang, W.; Zhan, S.; Liu, T.; Wang, D.; Wu, H. CDK5/FBW7-dependent ubiquitination and degradation of EZH2 inhibits pancreatic cancer cell migration and invasion. J. Biol. Chem. 2017, 292, 6269-6280. [CrossRef] [PubMed]

79. Consalvi, S.; Brancaccio, A.; Dall'Agnese, A.; Puri, P.L.; Palacios, D. Praja1 E3 ubiquitin ligase promotes skeletal myogenesis through degradation of EZH2 upon p38 $\alpha$ activation. Nat. commun. 2017, 8, 13956. [CrossRef] [PubMed]

80. Shen, Z.; Chen, L.; Yang, X.; Zhao, Y.; Pier, E.; Zhang, X.; Yang, X.; Xiong, Y. Downregulation of Ezh2 methyltransferase by FOXP3: New insight of FOXP3 into chromatin remodeling? Biochim. Biophys. Acta 2013, 1833, 2190-2200. [CrossRef] [PubMed]

81. Wang, X.; Cao, W.; Zhang, J.; Yan, M.; Xu, Q.; Wu, X.; Wan, L.; Zhang, Z.; Zhang, C.; Qin, X.; et al. A covalently bound inhibitor triggers EZH2 degradation through chip-mediated ubiquitination. EMBO J. 2017, 36, 1243-1260. [CrossRef] [PubMed]

82. Li, Z.; Hou, P.; Fan, D.; Dong, M.; Ma, M.; Li, H.; Yao, R.; Li, Y.; Wang, G.; Geng, P.; et al. The degradation of EZH2 mediated by IncRNA ANCR attenuated the invasion and metastasis of breast cancer. Cell Death Differ. 2017, 24, 59-71. [CrossRef] [PubMed]

83. Chen, Y.; Zhou, B.; Chen, D. USP21 promotes cell proliferation and metastasis through suppressing EZH2 ubiquitination in bladder carcinoma. Onco. Targets Ther. 2017, 10, 681-689. [CrossRef] [PubMed]

84. Zhang, P.; Xiao, Z.; Wang, S.; Zhang, M.; Wei, Y.; Hang, Q.; Kim, J.; Yao, F.; Rodriguez-Aguayo, C.; Ton, B.N.; et al. ZRANB1 is an EZH2 deubiquitinase and a potential therapeutic target in breast cancer. Cell Rep. 2018, 23, 823-837. [CrossRef] [PubMed]

85. Berry, W.L.; Janknecht, R. Kdm4/jmjd2 histone demethylases: Epigenetic regulators in cancer cells. Cancer Res. 2013, 73, 2936-2942. [CrossRef] [PubMed]

86. Ng, S.S.; Kavanagh, K.L.; McDonough, M.A.; Butler, D.; Pilka, E.S.; Lienard, B.M.; Bray, J.E.; Savitsky, P.; Gileadi, O.; von Delft, F; et al. Crystal structures of histone demethylase JMJD2a reveal basis for substrate specificity. Nature 2007, 448, 87-91. [CrossRef] [PubMed]

87. Guerra-Calderas, L.; Gonzalez-Barrios, R.; Herrera, L.A.; Cantu de Leon, D.; Soto-Reyes, E. The role of the histone demethylase KDM4A in cancer. Cancer Genet. 2015, 208, 215-224. [CrossRef] [PubMed]

88. Van Rechem, C.; Black, J.C.; Abbas, T.; Allen, A.; Rinehart, C.A.; Yuan, G.C.; Dutta, A.; Whetstine, J.R. The SKP1-Cul1-F-box and leucine-rich repeat protein 4 (SCF-FbxL4) ubiquitin ligase regulates lysine demethylase 4A (KDM4A)/jumonji domain-containing 2A (JMJD2A) protein. J. Biol. Chem. 2011, 286, 30462-30470. [CrossRef] [PubMed]

89. Tan, M.K.; Lim, H.J.; Harper, J.W. SCFFBXO22 regulates histone H3 lysine 9 and 36 methylation levels by targeting histone demethylase KDM4A for ubiquitin-mediated proteasomal degradation. Mol. Cell Biol. 2011, 31, 3687-3699. [CrossRef] [PubMed]

90. Mallette, F.A.; Mattiroli, F.; Cui, G.; Young, L.C.; Hendzel, M.J.; Mer, G.; Sixma, T.K.; Richard, S. RNF8and RNF168-dependent degradation of KDM4AJMJD2A triggers 53BP1 recruitment to DNA damage sites. EMBO J. 2012, 31, 1865-1878. [CrossRef] [PubMed]

91. Goldberg, A.D.; Allis, C.D.; Bernstein, E. Epigenetics: A landscape takes shape. Cell 2007, 128, 635-638. [CrossRef] [PubMed]

92. Shi, Y.; Lan, F.; Matson, C.; Mulligan, P.; Whetstine, J.R.; Cole, P.A.; Casero, R.A.; Shi, Y. Histone demethylation mediated by the nuclear amine oxidase homolog LSD1. Cell 2004, 119, 941-953. [CrossRef] [PubMed]

93. Schulte, J.H.; Lim, S.; Schramm, A.; Friedrichs, N.; Koster, J.; Versteeg, R.; Ora, I.; Pajtler, K.; Klein-Hitpass, L.; Kuhfittig-Kulle, S.; et al. Lysine-specific demethylase 1 is strongly expressed in poorly differentiated neuroblastoma: Implications for therapy. Cancer Res. 2009, 69, 2065-2071. [CrossRef] [PubMed]

94. Zhou, A.; Lin, K.; Zhang, S.; Chen, Y.; Zhang, N.; Xue, J.; Wang, Z.; Aldape, K.D.; Xie, K.; Woodgett, J.R.; et al. Nuclear GSK3 $\beta$ promotes tumorigenesis by phosphorylating KDM1A and inducing its deubiquitylation by USP22. Nat. Cell Biol. 2016, 18, 954-966. [CrossRef] [PubMed]

95. Kozono, D.; Li, J.; Nitta, M.; Sampetrean, O.; Gonda, D.; Kushwaha, D.S.; Merzon, D.; Ramakrishnan, V.; Zhu, S.; Zhu, K.; et al. Dynamic epigenetic regulation of glioblastoma tumorigenicity through LSD1 modulation of myc expression. Proc. Natl. Acad. Sci. USA 2015, 112, E4055-E4064. [CrossRef] [PubMed] 
96. Choi, H.J.; Park, J.H.; Park, M.; Won, H.Y.; Joo, H.S.; Lee, C.H.; Lee, J.Y.; Kong, G. UTX inhibits EMT-induced breast CSC properties by epigenetic repression of EMT genes in cooperation with LSD1 and HDAC1. EMBO Rep. 2015, 16, 1288-1298. [CrossRef] [PubMed]

97. Hayami, S.; Kelly, J.D.; Cho, H.S.; Yoshimatsu, M.; Unoki, M.; Tsunoda, T.; Field, H.I.; Neal, D.E.; Yamaue, H.; Ponder, B.A.; et al. Overexpression of LSD1 contributes to human carcinogenesis through chromatin regulation in various cancers. Int. J. Cancer 2011, 128, 574-586. [CrossRef] [PubMed]

98. Lim, S.; Janzer, A.; Becker, A.; Zimmer, A.; Schule, R.; Buettner, R.; Kirfel, J. Lysine-specific demethylase 1 (LSD1) is highly expressed in ER-negative breast cancers and a biomarker predicting aggressive biology. Carcinogenesis 2010, 31, 512-520. [CrossRef] [PubMed]

99. Ding, J.; Zhang, Z.M.; Xia, Y.; Liao, G.Q.; Pan, Y.; Liu, S.; Zhang, Y.; Yan, Z.S. LSD1-mediated epigenetic modification contributes to proliferation and metastasis of colon cancer. Br. J. Cancer 2013, 109, $994-1003$. [CrossRef] [PubMed]

100. Chen, J.; Ding, J.; Wang, Z.; Zhu, J.; Wang, X.; Du, J. Identification of downstream metastasis-associated target genes regulated by LSD1 in colon cancer cells. Oncotarget 2017, 8, 19609-19630. [CrossRef] [PubMed]

101. Feng, J.; Xu, G.; Liu, J.; Zhang, N.; Li, L.; Ji, J.; Zhang, J.; Zhang, L.; Wang, G.; Wang, X.; et al. Phosphorylation of LSD1 at Ser112 is crucial for its function in induction of EMT and metastasis in breast cancer. Breast Cancer Res. Treat. 2016, 159, 443-456. [CrossRef] [PubMed]

102. Wu, Y.; Zhou, B.P. Epigenetic regulation of LSD1 during mammary carcinogenesis. Mol. Cell Oncol. 2014, 1, e963426. [CrossRef] [PubMed]

103. Ambrosio, S.; Sacca, C.D.; Majello, B. Epigenetic regulation of epithelial to mesenchymal transition by the lysine-specific demethylase LSD1/KMD1A. Biochim. Biophys. Acta 2017, 1860, 905-910. [CrossRef] [PubMed]

104. Lin, Y.; Wu, Y.; Li, J.; Dong, C.; Ye, X.; Chi, Y.I.; Evers, B.M.; Zhou, B.P. The SNAG domain of Snail1 functions as a molecular hook for recruiting lysine-specific demethylase 1. EMBO J. 2010, 29, 1803-1816. [CrossRef] [PubMed]

105. Shi, Y.J.; Matson, C.; Lan, F.; Iwase, S.; Baba, T.; Shi, Y. Regulation of LSD1 histone demethylase activity by its associated factors. Mol. Cell 2005, 19, 857-864. [CrossRef] [PubMed]

106. Wu, Y.; Wang, Y.; Yang, X.H.; Kang, T.; Zhao, Y.; Wang, C.; Evers, B.M.; Zhou, B.P. The deubiquitinase USP28 stabilizes LSD1 and confers stem-cell-like traits to breast cancer cells. Cell Rep. 2013, 5, 224-236. [CrossRef] [PubMed]

107. Yi, L.; Cui, Y.; Xu, Q.; Jiang, Y. Stabilization of LSD1 by deubiquitinating enzyme USP7 promotes glioblastoma cell tumorigenesis and metastasis through suppression of the p53 signaling pathway. Oncol. Rep. 2016, 36, 2935-2945. [CrossRef] [PubMed]

108. Han, X.; Gui, B.; Xiong, C.; Zhao, L.; Liang, J.; Sun, L.; Yang, X.; Yu, W.; Si, W.; Yan, R.; et al. Destabilizing LSD1 by Jade-2 promotes neurogenesis: An antibraking system in neural development. Mol. Cell 2014, 55, 482-494. [CrossRef] [PubMed]

109. Panchenko, M.V. Structure, function and regulation of Jade family PHD finger 1 (JADE1). Gene 2016, 589, 1-11. [CrossRef] [PubMed]

110. Chen, B.B.; Mallampalli, R.K. F-box protein substrate recognition: A new insight. Cell Cycle 2013, 12, 1009-1010. [CrossRef] [PubMed]

111. Lai, Y.; Li, J.; Li, X.; Zou, C. LPS modulates p300 and Sirt1 to promote PRMT1 stability via an SCF-Fbxl17-recognized acetyldegron. J. Cell Sci. 2017, 130, 3578-3587. [CrossRef] [PubMed]

112. Hirata, Y.; Katagiri, K.; Nagaoka, K.; Morishita, T.; Kudoh, Y.; Hatta, T.; Naguro, I.; Kano, K.; Udagawa, T.; Natsume, T.; et al. TRIM48 promotes ASK1 activation and cell death through ubiquitination-dependent degradation of the ASK1-negative regulator prmt1. Cell Rep. 2017, 21, 2447-2457. [CrossRef] [PubMed]

113. Bhuripanyo, K.; Wang, Y.; Liu, X.; Zhou, L.; Liu, R.; Duong, D.; Zhao, B.; Bi, Y.; Zhou, H.; Chen, G.; et al. Identifying the substrate proteins of U-box E3s E4B and CHIP by orthogonal ubiquitin transfer. Sci. Adv. 2018, 4, e1701393. [CrossRef] [PubMed]

114. Cha, B.; Park, Y.; Hwang, B.N.; Kim, S.Y.; Jho, E.H. Protein arginine methyltransferase 1 methylates Smurf2. Mol. Cells 2015, 38, 723-728. [CrossRef] [PubMed]

115. Tikhanovich, I.; Kuravi, S.; Artigues, A.; Villar, M.T.; Dorko, K.; Nawabi, A.; Roberts, B.; Weinman, S.A. Dynamic arginine methylation of tumor necrosis factor (TNF) receptor-associated factor 6 regulates toll-like receptor signaling. J. Biol. Chem. 2015, 290, 22236-22249. [CrossRef] [PubMed] 
116. Wang, L.; Zhao, Z.; Meyer, M.B.; Saha, S.; Yu, M.; Guo, A.; Wisinski, K.B.; Huang, W.; Cai, W.; Pike, J.W.; et al. CARM1 methylates chromatin remodeling factor BAF155 to enhance tumor progression and metastasis. Cancer Cell 2014, 25, 21-36. [CrossRef] [PubMed]

117. Habashy, H.O.; Rakha, E.A.; Ellis, I.O.; Powe, D.G. The oestrogen receptor coactivator CARM1 has an oncogenic effect and is associated with poor prognosis in breast cancer. Breast Cancer Res. Treat. 2013, 140, 307-316. [CrossRef] [PubMed]

118. Shin, H.J.; Kim, H.; Oh, S.; Lee, J.G.; Kee, M.; Ko, H.J.; Kweon, M.N.; Won, K.J.; Baek, S.H. AMPK-SKP2-CARM1 signalling cascade in transcriptional regulation of autophagy. Nature 2016, 534, 553-557. [CrossRef] [PubMed]

119. Li, C.; Yu, L.; Xue, H.; Yang, Z.; Yin, Y.; Zhang, B.; Chen, M.; Ma, H. Nuclear AMPK regulated CARM1 stabilization impacts autophagy in aged heart. Biochem. Biophys. Res. Commun. 2017, 486, 398-405. [CrossRef] [PubMed]

120. Kim, D.; Lim, S.; Park, M.; Choi, J.; Kim, J.; Han, H.; Yoon, K.; Kim, K.; Lim, J.; Park, S. Ubiquitination-dependent CARM1 degradation facilitates Notch1-mediated podocyte apoptosis in diabetic nephropathy. Cell. Signal. 2014, 26, 1774-1782. [CrossRef] [PubMed]

121. Li, X.; Lai, Y.; Li, J.; Zou, M.; Zou, C. Oxidative stress destabilizes protein arginine methyltransferase 4 via glycogen synthase kinase $3 \beta$ to impede lung epithelial cell migration. Am. J. Phys. Cell Phys. 2017, 313, C285-C294. [CrossRef] [PubMed]

122. Janzen, W.P.; Wigle, T.J.; Jin, J.; Frye, S.V. Epigenetics: Tools and technologies. Drug Discov. Today Technol. 2010, 7, e59-e65. [CrossRef] [PubMed]

123. Filippakopoulos, P.; Knapp, S. Targeting bromodomains: Epigenetic readers of lysine acetylation. Nat. Rev. Drug Discov. 2014, 13, 337-356. [CrossRef] [PubMed]

124. Dey, A.; Chitsaz, F.; Abbasi, A.; Misteli, T.; Ozato, K. The double bromodomain protein Brd 4 binds to acetylated chromatin during interphase and mitosis. Proc. Natl. Acad. Sci. USA 2003, 100, 8758-8763. [CrossRef] [PubMed]

125. Dai, X.; Gan, W.; Li, X.; Wang, S.; Zhang, W.; Huang, L.; Liu, S.; Zhong, Q.; Guo, J.; Zhang, J.; et al. Prostate cancer-associated SPOP mutations confer resistance to BET inhibitors through stabilization of BRD4. Nat. Med. 2017, 23, 1063-1071. [CrossRef] [PubMed]

126. Wang, C.Y.; Filippakopoulos, P. Beating the odds: BETs in disease. Trends Biochem. Sci. 2015, 40, 468-479. [CrossRef] [PubMed]

127. Shi, J.; Wang, Y.; Zeng, L.; Wu, Y.; Deng, J.; Zhang, Q.; Lin, Y.; Li, J.; Kang, T.; Tao, M.; et al. Disrupting the interaction of BRD4 with diacetylated Twist suppresses tumorigenesis in basal-like breast cancer. Cancer Cell 2014, 25, 210-225. [CrossRef] [PubMed]

128. Zhang, P.; Wang, D.; Zhao, Y.; Ren, S.; Gao, K.; Ye, Z.; Wang, S.; Pan, C.W.; Zhu, Y.; Yan, Y.; et al. Intrinsic BET inhibitor resistance in SPOP-mutated prostate cancer is mediated by BET protein stabilization and AKT-mTORC1 activation. Nat. Med. 2017, 23, 1055-1062. [CrossRef] [PubMed]

129. Janouskova, H.; El Tekle, G.; Bellini, E.; Udeshi, N.D.; Rinaldi, A.; Ulbricht, A.; Bernasocchi, T.; Civenni, G.; Losa, M.; Svinkina, T.; et al. Opposing effects of cancer-type-specific SPOP mutants on BET protein degradation and sensitivity to BET inhibitors. Nat. Med. 2017, 23, 1046-1054. [CrossRef] [PubMed]

130. Akuffo, A.A.; Alontaga, A.Y.; Metcalf, R.; Beatty, M.S.; Becker, A.; McDaniel, J.M.; Hesterberg, R.S.; Goodheart, W.E.; Gunawan, S.; Ayaz, M.; et al. Ligand-mediated protein degradation reveals functional conservation among sequence variants of the CUL4-type E3 ligase substrate receptor cereblon. J. Biol. Chem. 2018, 293, 6187-6200. [CrossRef] [PubMed]

131. Jin, X.; Yan, Y.; Wang, D.; Ding, D.; Ma, T.; Ye, Z.; Jimenez, R.; Wang, L.; Wu, H.; Huang, H. DUB3 promotes BET inhibitor resistance and cancer progression by deubiquitinating BRD4. Mol. Cell 2018, 71, 592-605.e594. [CrossRef] [PubMed]

(C) 2018 by the authors. Licensee MDPI, Basel, Switzerland. This article is an open access article distributed under the terms and conditions of the Creative Commons Attribution (CC BY) license (http:/ / creativecommons.org/licenses/by/4.0/). 